\title{
Sediment denitrification in the Gulf of Mexico zone of hypoxia
}

\author{
Carl R. Childs ${ }^{1}$, Nancy N. Rabalais ${ }^{2}$, R. Eugene Turner $^{3}$, Lita M. Proctor ${ }^{4,5, *}$ \\ ${ }^{1}$ Department of Oceanography, Florida State University, West Call Street, Tallahassee, Florida 32306-4320, USA \\ ${ }^{2}$ Louisiana Universities Marine Consortium, 8124 Highway 56, Chauvin, Louisiana 70344, USA \\ ${ }^{3}$ Coastal Ecology Institute, Louisiana State University, South Stadium Road, Baton Rouge, Louisiana 70803, USA \\ ${ }^{4}$ US Geological Survey, National Research Program, Water Resources Division, MS 430, 12201 Sunrise Valley Drive, Reston, \\ Virginia 20192, USA \\ ${ }^{5}$ Center of Marine Biotechnology, University of Maryland Biotechnology Institute, 701 East Pratt Street, \\ Baltimore, Maryland 21202, USA
}

\begin{abstract}
The largest zone of anthropogenic bottom water hypoxia in the Western Hemisphere occurs seasonally in the northern Gulf of Mexico between the Mississippi River delta and the coast of eastern Texas. This zone of hypoxia reaches its greatest extent in the summer months and is a consequence of seasonal stratification of the water column combined with the decomposition of organic matter derived from accelerated rates of primary production. This enhanced productivity is driven primarily by the input of inorganic nitrogen from the Mississippi River. There are 3 likely sinks for fixed nitrogen within this zone of hypoxia: sequestration in the sediment, dispersion and dilution into the Gulf of Mexico, and denitrification. We assessed potential denitrification rates at 7 stations in the zone of hypoxia during the summer of 1999. Those data are compared with bottom water nitrate, ammonium and dissolved oxygen (DO) concentrations. No denitrification was observed in the water column. Denitrification potential rates in the surface sediments were unexpectedly low and ranged between 39.8 and $108.1 \mu \mathrm{mol} \mathrm{m} \mathrm{m}^{-2} \mathrm{~h}^{-1}$. The highest rates were observed at stations with bottom water DO concentrations between 1 and $3 \mathrm{mg} \mathrm{l}^{-1}$. Denitrification activity was significantly lower at stations where DO was lower than $1 \mathrm{mg} \mathrm{l}^{-1}$ or higher than $3 \mathrm{mg} \mathrm{l}^{-1}$. Nutrient data for these stations demonstrate that as anoxia is approached, the dominant species of nitrogen shifts from nitrate to ammonium. The shift in nitrogen species suggests competition between microbial populations in the sediment community. The lower denitrification rates at stations with bottom water $\mathrm{DO}<1 \mathrm{mg} \mathrm{l}^{-1}$ may be due to nitrate limitation or an increase in the competitive advantage of microorganisms capable of dissimilatory nitrate reduction to ammonium (DNRA). Suppression of denitrification at low DO by any mechanism will increase the residence time of bioavailable nitrogen. This trend could act as a positive feedback mechanism in the formation of hypoxic bottom waters.
\end{abstract}

KEY WORDS: Sediment - Denitrification - Gulf of Mexico · Hypoxia

Resale or republication not permitted without written consent of the publisher

\footnotetext{
*Corresponding author. E-mail: lmprocto@usgs.gov
}

The waters of the Mississippi River plume are highly productive with annual carbon fixation estimated to be near or slightly over $320 \mathrm{~g} \mathrm{C} \mathrm{m}^{-2} \mathrm{yr}^{-1}$ (Lohrenz et al. 1990). This high productivity is directly proportional to river-borne dissolved inorganic nutrient inputs (Justić et al. 1993, Lohrenz et al. 1997, 1999). Nutrient loading has increased substantially over the last half century in the Mississippi River plume (Turner \& Rabalais 1991, Goolsby et al. 1999). In a parallel time sequence, the accumulation of marine-origin phytoplankton carbon (Eadie et al. 1994), and in particular diatoms (Turner \& Rabalais 1994), as evidenced by paleoindicators from sediments beneath the Mississippi River plume, have also increased and have done so in direct proportion to the increased nutrient loads.

Nitrate discharge from the river and primary production are both at a maximum during the late spring to early summer (Lohrenz et al. 1997) and coincide with the period of maximum stratification of the water column (Dinnel \& Wiseman 1985, Cochrane \& Kelly 1986). This nutrient loading combined with seasonal stratification of the water column results in the formation of the largest zone of anthropogenic bottom water hypoxia $\left(<2 \mathrm{mg} \mathrm{O}_{2} \mathrm{l}^{-1}\right)$ in the Western Hemisphere. Bottom water and benthic respiration rates on the Louisiana continental shelf are high enough to deplete the bottom water of oxygen within 1 mo (Dortch et al. 1994, Amon \& Benner 1998). This hypoxic zone can exist from April to October.

There have been several investigations into the microbial ecology of the Mississippi River plume. However, these have focused largely on the surface waters. Chin-Leo \& Benner (1992) and Cotner \& Gardner (1993) both investigated bacterial production in the surface waters and found that production was highest at intermediate salinities. Pakulski et al. (1995) likewise found high rates of carbon remineralization at salinities of 18 
and 27 PSU and proposed that nitrification could account for 20 to $>50 \%$ of community oxygen demand. Cotner \& Gardner (1993) found that ammonium regeneration rates in the plume were an order of magnitude higher during the summer than in the winter and concluded that dissolved amino acids are the likely substrate for this regeneration.

The microbial ecology of the sediments and hypoxic bottom water has not been as well documented as surface processes and investigations of anaerobic microbial processes on the Louisiana Continental Shelf are particularly lacking. The fluxes of organic matter combined with low dissolved oxygen (DO) and high nitrate concentrations suggest that anaerobic processes and denitrification rates, in particular, should be quite high in the Louisiana Shelf zone of hypoxia. Gardner et al. (1993) has been the only study to report denitrification rates for this area. They estimated denitrification rates at 4 stations using benthic flux chambers on the Louisiana Shelf in July of 1990 and reported rates between 21.0 and $69.6 \mu \mathrm{g}$ atom $\mathrm{N} \mathrm{m}^{-2} \mathrm{~h}^{-1}$.

Denitrification is a form of anaerobic microbial respiration in which nitrate or nitrite is reduced to nitrous oxide or dinitrogen. It is a major sink for bioavailable nitrogen. All known denitrifying bacteria are facultative anaerobes, i.e. they are capable of using either the nitrogen oxides or oxygen in respiration. These bacteria only begin to denitrify when the nitrogen oxides are present and oxygen concentration is low (Zumft 1997). However, low oxygen concentrations can also limit denitrification by inhibiting nitrification - the oxidation of ammonium to nitrate - thus, increasing ammonium regeneration. Tiedje et al. (1982) also proposed that very low oxygen concentrations could favor dissimilatory nitrate reduction to ammonia (DNRA) over denitrification. DNRA is another form of anaerobic res- piration in which nitrate or nitrite is reduced completely to ammonium.

The input of fixed nitrogen is one of the defining characteristics of the ecology of the Louisiana Shelf. Understanding the local dynamics of denitrification is critical to developing a more complete understanding of this system. In this paper, we report potential sediment denitrification rates measured at 7 different stations on the Louisiana Shelf during the peak of the hypoxic season in 1999. These data are compared with contemporaneous water quality data. The role of DO and the concentration of nitrogenous species in regulating denitrification are examined, and the relationship between various pathways of nitrate reduction is discussed. Potential denitrification rates in the Louisiana Shelf zone of hypoxia are compared with reported rates from other systems.

\section{MATERIALS AND METHODS}

Study site and hydrographic data. In July 1999, the zone of seasonal bottom water hypoxia in the northern Gulf of Mexico was surveyed on a transect cruise aboard the RV 'Pelican'. The cruise covered an area of more than $20000 \mathrm{~km}^{2}$ with 83 stations along 13 transects between $29^{\circ} 08^{\prime} \mathrm{N}, 89^{\circ} 28^{\prime} \mathrm{W}$ and $29^{\circ} 17^{\prime} \mathrm{N}$, $92^{\circ} 48^{\prime} \mathrm{W}$ (Fig. 1). Hydrographic data and water samples were collected at each station. Hydrographic data were obtained using a SeaBird 911+ CTD system and a Hydrolab Surveyor 3. Data collected included temperature, $\mathrm{pH}, \mathrm{DO}$, conductivity, salinity, fluorescence, $\%$ light transmission and depth. Oxygen sensor end point calibrations were made prior to the cruise and Winkler titrations were conducted aboard ship to confirm the accuracy of instrumental values for DO.

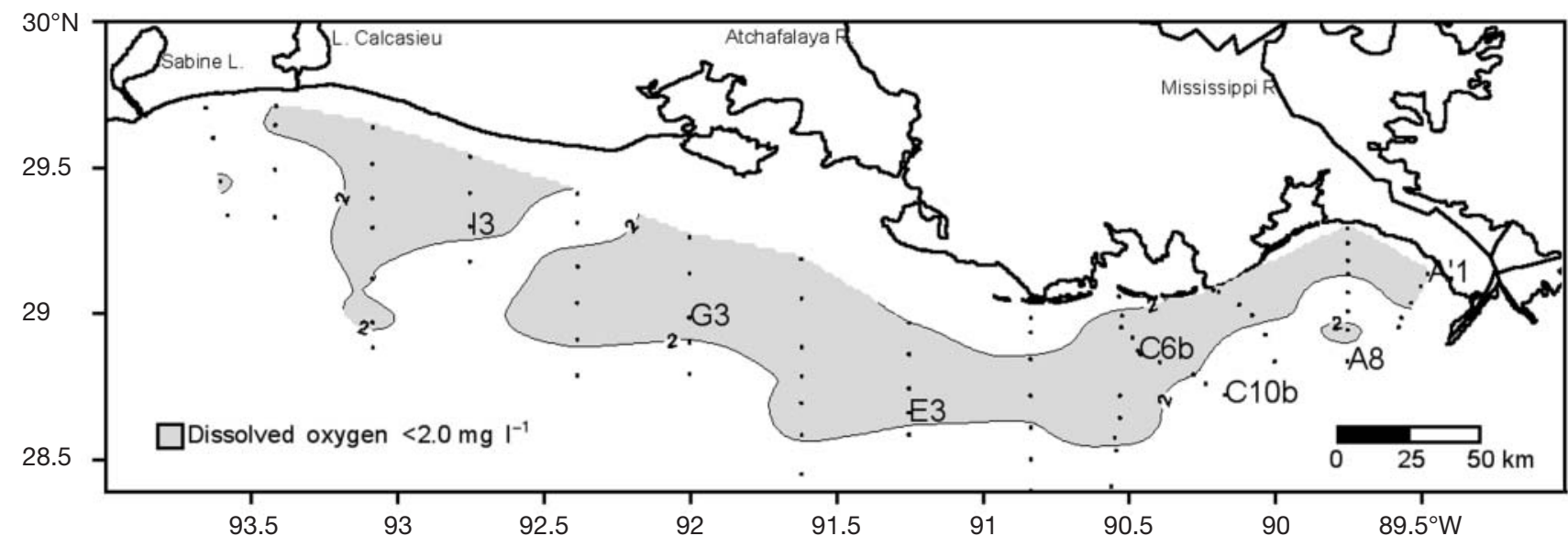

Fig. 1. Location of sample stations and the extent of hypoxia in the summer of 1999. Number-letter combinations designate the stations where sediment cores were collected 
Nutrient analysis. Water samples for chlorophyll (chl a), nutrients, oxygen and salinity analyses were collected from the surface, midwater and bottom water. Surface water samples were collected by bucket, and midwater and bottom water samples were collected with 51 Niskin bottles. Water samples for nutrient analysis were frozen on board at $-20^{\circ} \mathrm{C}$ for later analysis at Louisiana State University. Nitrogen species were analyzed according to methods described in EPA Publication EPA 600/4-79-020 (1979), Method 350.1 for ammonia-N and Method 353.2 for nitrate/nitrite-N.

Denitrification potential assays. Denitrification potential was assessed in the surface water, bottom water and sediments. Intact sediment cores were collected at 7 different stations (Fig. 1) using a box-coring device. The denitrification potential was assessed using a modification of the acetylene inhibition technique described by Sorensen (1978). Sediment samples were collected using a box-coring device. The box core was subcored using $5 \mathrm{~cm}$ diameter butyrate cores. Maintaining a layer of water over the sediment surface reduced oxygenation of the sediment. The top $1 \mathrm{~cm}$ of sediment was incubated anaerobically in $160 \mathrm{ml}$ serum bottles in a medium containing $50 \mathrm{ml}$ of aged, filtered seawater amended to $100 \mu \mathrm{M} \mathrm{KNO}_{3}{ }^{-}$and a head space containing $90 \%$ UZ grade (ultra high purity) $\mathrm{N}_{2}(\mathrm{~g}$ ) and $10 \% \mathrm{C}_{2} \mathrm{H}_{2}(\mathrm{~g})$. Water samples from above and below the pycnocline were collected in Niskin bottles. Water samples of $50 \mathrm{ml}$ were incubated anaerobically in $160 \mathrm{ml}$ serum bottles with a head space space containing $90 \%$ UZ grade $\mathrm{N}_{2}(\mathrm{~g})$ and $10 \% \mathrm{C}_{2} \mathrm{H}_{2}(\mathrm{~g})$. After incubation, samples of the headspace gas from the water and the sediment incubations were transferred to $10 \mathrm{ml}$ Vacutainers ${ }^{\mathrm{TM}}$. The gas samples were refrigerated and returned to Florida State University for analysis. The gas samples were assayed for $\mathrm{N}_{2} \mathrm{O}$ concentration using a Shimadzu GC-8A gas chromatograph (Porpak Q column) equipped with an electron capture detector $\left(350^{\circ} \mathrm{C}\right)$. The linearity of $\mathrm{N}_{2} \mathrm{O}$ production over varying incubation periods was confirmed in 2 time course experiments conducted on board with incubation times of 1,2 and $4 \mathrm{~h}$.

\section{RESULTS}

The areal extent of the Gulf of Mexico zone of hypoxia in the summer of 1999 was over $20000 \mathrm{~km}^{2}$. This was the largest recorded area of bottom water hypoxia in this region since regular cruises began charting this phenomenon in 1985.

Bottom water dissolved inorganic nitrogen (DIN) (nitrate + nitrite + ammonium) concentrations ranged between 11.5 and $41.0 \mu \mathrm{M}$ at all stations where sediment cores were collected (Table 1 ). The species composition of this nitrogen pool was closely correlated with DO concentration. As oxygen concentrations increased, the percentage of DIN in higher oxidation states increased. The lowest levels of total DIN occurred at stations where DO was between 1 and $3 \mathrm{mg} \mathrm{l}^{-1}$.

Nitrate concentrations ranged between 1.9 and $26.8 \mu \mathrm{M}$ with peak concentrations at stations with a DO of $0.4 \mathrm{mg} \mathrm{l}^{-1}$ or greater. Ammonium concentrations displayed the greatest range, with concentrations between 0.1 and $37.4 \mu \mathrm{M}$. Ammonium concentrations were significantly higher at stations where DO was below $0.4 \mathrm{mg} \mathrm{l}^{-1}$ (Fig. 2).

No nitrous oxide production was observed in any of the water samples. Denitrification potential rates in the sediment ranged between 39.7 and $108.1 \mu \mathrm{mol} \mathrm{N}$ $\mathrm{m}^{-2} \mathrm{~h}^{-1}$ (Table 1). The highest rates were observed at stations where the bottom water DO concentration was between 1 and $3 \mathrm{mg} \mathrm{l}^{-1}$ (Fig. 2). The lowest rates were observed at Stn $\mathrm{C} 10 \mathrm{~b}$ where the DO concentration was $5.18 \mathrm{mg} \mathrm{l}^{-1}$. Denitrification rates at the stations where DO was below $1 \mathrm{mg} \mathrm{l}^{-1}$ were approximately $1 / 2$ the rates found at stations where the DO was between 1 and $3 \mathrm{mg} \mathrm{l}^{-1}$. This decline in denitrification rates at low DO was unexpected.

The time course assays showed that $\mathrm{N}_{2} \mathrm{O}$ production in our experiments was linear $\left(\mathrm{R}^{2}=0.93\right)$ over the duration of our incubations (data not shown). Thus, we feel confident in inferring denitrification rates from endpoint incubations. Variability among replicate cores was slight at most stations, with an average coefficient of variation of 0.18 .

Table 1. Station location, bottom water concentrations for dissolved oxygen (DO), salinity, nitrate, nitrite and ammonium, and surface sediment denitrification potential $\left(\mu \mathrm{mol} \mathrm{N} \mathrm{m}{ }^{-2} \mathrm{~h}^{-1}\right) \pm \mathrm{SD}$, from 7 stations on the Louisiana Continental Shelf in July 1999

\begin{tabular}{|lccccccc|}
\hline Stn & Location & $\begin{array}{c}\mathrm{DO} \\
\left(\mathrm{mg} \mathrm{l}^{-1}\right)\end{array}$ & $\begin{array}{c}\text { Salinity } \\
(\mathrm{PSU})\end{array}$ & $\begin{array}{c}\mathrm{NO}_{3}^{-} \\
(\mu \mathrm{M})\end{array}$ & $\begin{array}{c}\mathrm{NO}_{2}{ }^{-} \\
(\mu \mathrm{M})\end{array}$ & $\begin{array}{c}\mathrm{NH}_{4}{ }^{+} \\
(\mu \mathrm{M})\end{array}$ & $\begin{array}{c}\text { Denitrification }\left( \pm \mathrm{SD}^{-}\right) \\
\left(\mu \mathrm{mol} \mathrm{N} \mathrm{m}^{-2} \mathrm{~h}^{-1}\right)\end{array}$ \\
\hline $\mathrm{A}^{\prime} 1$ & $29.1^{\circ} \mathrm{N}, 89.3^{\circ} \mathrm{W}$ & 0.3 & 32.3 & 2.9 & 0.7 & 37.4 & $58.2( \pm 9.5)$ \\
$\mathrm{A} 8$ & $28.8^{\circ} \mathrm{N}, 89.75^{\circ} \mathrm{W}$ & 2.8 & 36.2 & 9.3 & 1.8 & 1.4 & $108.1( \pm 13.8)$ \\
$\mathrm{C} 6 \mathrm{~b}$ & $28.85^{\circ} \mathrm{N}, 90.3^{\circ} \mathrm{W}$ & 0.4 & 35.2 & 10.9 & 6.2 & 4.1 & $47.9( \pm 6.9)$ \\
$\mathrm{C} 10 \mathrm{~b}$ & $28.75^{\circ} \mathrm{N}, 90.2^{\circ} \mathrm{W}$ & 5.2 & 36.1 & 26.8 & 1.2 & 1.8 & $39.8( \pm 14.5)$ \\
$\mathrm{E} 3$ & $28.75^{\circ} \mathrm{N}, 91.25^{\circ} \mathrm{W}$ & 1.6 & 35.2 & 10.7 & 0.7 & 0.1 & $103.3( \pm 14.5)$ \\
$\mathrm{G} 3$ & $28.6^{\circ} \mathrm{N}, 92.0^{\circ} \mathrm{W}$ & 0.9 & 34.7 & 13.1 & 2.4 & 1.9 & $69.3( \pm 12.6)$ \\
I3 & $29.0^{\circ} \mathrm{N}, 92.75^{\circ} \mathrm{W}$ & 0.3 & 34.3 & 1.9 & 0.6 & 14.0 & $63.1( \pm 9.6)$ \\
\hline
\end{tabular}




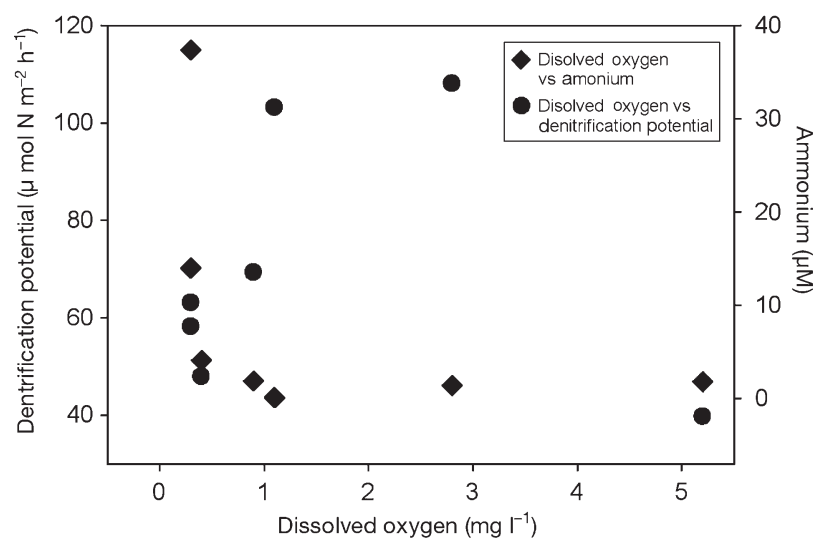

Fig. 2. Bottom water ammonium concentration $(\mu \mathrm{M})$ and surface sediment denitrification potential $\left(\mu \mathrm{mol} \mathrm{N} \mathrm{m} \mathrm{N}^{-2} \mathrm{~h}^{-1}\right)$ as a function of bottom water dissolved oxygen concentration (mg $\mathrm{l}^{-1}$ ). There is a pronounced accumulation of ammonium and decrease in denitrification potential as anoxic conditions are approached

\section{DISCUSSION}

The potential denitrification rates we measured are consistent with the earlier estimates made by Gardner et al. (1993). These rates are at the low end of denitrification rates reported from other systems (Herbert 1999). This was unexpected because the current paradigm for denitrification suggests that the conditions in the hypoxic zone (high carbon, low oxygen and high nitrate) should be ideal for denitrification. However, reported denitrification rates show a wide range of values with the highest rates found in fresh water environments or in shallow nearshore marine waters (Herbert 1999). Additionally, in situ denitrification rates could be somewhat lower because our method measures the maximum potential denitrification capability of the sediment. Such problems are typical of denitrification measurements because there is no consensus method for measuring this process (Seitzinger et al. 1993). Our data presented here are a reasonable estimate of the enzymatic potential for denitrification in the microbial community.

There are several factors that might explain why denitrification potential would be lower than expected in the hypoxic zone. Reduced metabolic activity in the hypoxic zone has also been found in other studies (Dortch et al. 1994). They found that aerobic respiration rates for both the bottom water and the benthos were lower than rates compiled for other estuaries. There may also be factors that act to specifically restrict denitrification on the Louisiana Shelf. Other more obligatory anaerobic organisms, such as sulfate reducers, may dominate this system. Indeed, sulfate reduction has been shown to play a major role in the bottom water biogeochemistry during summer hypoxia in the Chesapeake Bay (Kemp et al. 1990). Additionally, hydrogen sulfide, the product of sulfate reduction, is a respiratory poison (Wang \& Chapman 1999) and has been shown to specifically inhibit nitrification, the oxidation of ammonium to nitrate (Joye \& Hollibaugh 1995). The DNRA may also be competing with denitrification for nitrate (Tiedje 1988). However, ammonium concentrations at our sampling stations and thermodynamic considerations suggest that DNRA does not occur until DO approaches anoxia (Tiedje 1982).

In addition to finding that potential denitrification rates were lower than expected throughout the hypoxic zone, there were significant differences in denitrification potential among the 7 stations sampled. It is unclear why denitrification potential would be lower at stations where DO concentrations were below $1 \mathrm{mg} \mathrm{l}^{-1}$ than at stations where DO was higher. It is possible that the low oxygen concentration limits nitrification and thus, indirectly limits denitrification. However, limitation of denitrification by this path is likely to be restricted to environments with little to no ambient nitrate (Sloth et al. 1995). The nitrate concentration at Stn C6b, a station with one of the lowest denitrification rates in our study, was $10.9 \mu \mathrm{M}$, well above the nitrate concentrations reported to limit denitrification by Sloth et al. (1995). Thus, nitrate limitation does not seem to be a complete explanation for the observed changes in denitrification potential. Lower denitrification rates at stations with DO $<1 \mathrm{mg} \mathrm{l}^{-1}$ could be the result of an increase in the competitive advantage of DNRA (Tiedje et al. 1982). DNRA becomes favored as the concentration of electron acceptors becomes increasingly limited because DNRA accommodates more electrons per molecule of nitrate (8) than denitrification (5). The significant increase in ammonium concentrations at stations with nearly anoxic conditions supports the proposition that DNRA could be a significant process at these stations. Additional investigations are necessary to assess the significance of DNRA in this region.

It is now recognized that impacted coastal marine ecosystems are characterized by increases in the numbers and activities of microbial populations, the socalled 'microbialization of the coastal ocean' (Jackson et al. 2001). In our study, we demonstrate that the microbial communities in impacted systems do not only increase in numbers and activity, but also increase in the complex interactions between microbial populations, with unexpected consequences. In the Louisiana shelf hypoxic zone, competing microbial processes led to the inhibition of some microbial pathways and the stimulation of others, promoting further retention of bioavailable $\mathrm{N}$ in the system. Understanding these microbial interactions will be important for mitigation of these impacted systems. 
The Louisiana shelf has one of the most productive fisheries in the United States with an annual harvest exceeding $\$ 270$ million (CAST 1999). This industry could be dramatically impacted by hypoxia. Similar processes of anthropogenic hypoxia have been observed in the Baltic Sea, the Black Sea, the Mediterranean Sea, and numerous smaller bays and estuaries. Frequently, the reduction or complete collapse of local fisheries follows the formation of these hypoxic zones (Diaz \& Rosenberg 1995). The Louisiana Shelf zone of hypoxia is a consequence of anthropogenic nutrient loading. Determining the fate of fixed nitrogen on the Louisiana Shelf will be critical to remediating this problem.

The data presented here suggest the possibility of a positive feedback loop between the severity of hypoxia and the residence time of fixed nitrogen. In this study, it was observed that denitrification was suppressed under conditions of severe hypoxia (DO $<1.0 \mathrm{mg} \mathrm{l}^{-1}$ ). Suppression of sediment denitrification will effectively act to increase the benthic flux of bioavailable nitrogen to the water column. Benthic flux of nutrients to the water column is frequently associated with increased primary productivity (Twilley et al. 1999) — a primary factor in the formation of the hypoxic zone-thus exacerbating hypoxic conditions.

Acknowledgements. Funding to support this research came from US Department of Energy, no. PROC-DE-FG02-97ER (to L.M.P.), National Oceanic and Atmospheric Administration, Coastal Ocean Program, no. NA96OP0112 (to N.N.R.) and no. NA06OP0529 (to R.E.T.)

\section{LITERATURE CITED}

Amon RMW, Benner R (1998) Seasonal patterns of bacterial abundance and production in the Mississippi River plume and their importance for the fate of enhanced primary production. Microb Ecol 35:289-300

Caffrey JM, Sloth NP, Kaspar HF, Blackburn TH (1993) Effect of organic loading on nitrification and denitrification in a marine sediment microcosm. FEMS Microbiol Ecol 12: $159-167$

Carter JP, Hsiao YH, Spiro S, Richardson DJ (1995) Soil and sediment bacteria capable of aerobic nitrate respiration. Appl Environ Microbiol 61(8):2852-2858

Caskey WH, Tiedje JM (1979) Evidence for Clostridia as agents for of dissimilatory reduction of nitrate to ammonium in soils. Soil Sci Soc Am J 43:931-935

Caskey WH, Tiedje JM (1980) The reduction of nitrate to ammonium by a Clostridium sp. isolated from soil. J Gen Microbiol 119:217-223

CAST (1999) (Council for Agricultural Science and Technology) Gulf of Mexico Hypoxia. Task Force Report No. 134, Washington, DC

Chin-Leo G, Benner R (1992) Enhanced bacterioplankton production and respiration at intermediate salinities in the Mississippi River plume. Mar Ecol Prog Ser 87:87-103

Cochrane JD, Kelly FJ (1986) Low-frequency circulation on the Texas-Louisiana continental shelf. J Geophys Res 91: 10645-10659

Cotner JB Jr, Gardner WS (1993) Heterotrophic bacterial mediation of ammonium and dissolved free amino acid fluxes in the Mississippi River plume. Mar Ecol Prog Ser 93:75-87

Diaz RJ, Rosenberg R (1995) Marine benthic hypoxia: a review of its ecological effects and the behavioral responses of benthic macrofauna. Oceanogr Mar Biol Annu Rev 33:245-303

Dinnel SP, Wiseman WJ Jr (1986) Freshwater on the Louisiana shelf. Cont Shelf Res 6:765-784

Dortch Q, Rabalais NN, Turner RE, Rowe GT (1994) Respiration rates and hypoxia on the Louisiana shelf. Estuaries 17: 862-872

Eadie BJ, McKee BA, Lansing MB, Robbins JA, Metz S, Trefry JH (1994) Records of nutrient enhanced coastal ocean productivity in sediments from the Louisiana continental shelf. Estuaries 17:754-765

Gardner WS, Briones EE, Kaegi EC, Rowe GT (1993) Ammonium excretion by benthic invertebrates and sedimentwater nitrogen flux in the Gulf of Mexico near the Mississippi River plume. Estuaries 16(4):799-808

Goolsby DA, Battaglin WA, Lawrence GB, Artz RS, Aulenbach BT, Hooper RP, Keeney DR, Stensland GJ (1999) Flux and sources of nutrients in the Mississippi-Atchafalaya River Basin. Topic 3 Report for the Integrated Assessment of Hypoxia in the Gulf of Mexico. NOAA Coastal Ocean Program Decision Analysis Series No. 17. NOAA Coastal Ocean Program, Silver Springs, MD

Herbert RA (1999) Nitrogen cycling in coastal marine systems. FEMS Microbiol Rev 23:563-590

Jackson JBC, Kirby MX, Berger WH, Bjorndal KA and 15 others (2001) Historical overfishing and the recent collapse of coastal ecosystems. Science 293:629-638

Joye SB, Hollibaugh JT (1995) Influence of sulfide inhibition of nitrification on nitrogen regeneration in sediments. Science 270:623-625

Justić D, Rabalais NN, Turner RE, Wiseman WJ Jr (1993) Seasonal coupling between river-borne nutrients, net productivity and hypoxia. Mar Pollut Bull 26:184-189

Kemp WM, Sampou P, Caffrey J, Mayer M, Henriksen K, Boynton WR (1990) Ammonium recycling versus denitrification in Chesapeake Bay sediments. Limnol Oceanogr 35(7):1545-1563

Lohrenz SE, Dagg MJ, Whitledge TE (1990) Enhanced primary production at plume/oceanic interface of the Mississippi River. Cont Shelf Res 10:639-664

Lohrenz SE, Fahnenstiel GL, Redalje DG, Lang GA, Chen X, Dagg MJ (1997) Variations in primary production of the northern Gulf of Mexico continental shelf waters linked to nutrient inputs from the Mississippi River. Mar Ecol Prog Ser 155:435-454

Lohrenz SE, Fahnenstiel GL, Redalje DG, Lang GA, Chen X, Dagg MJ, Whitledge TE, Dortch Q (1999) Nutrients, irradiance, and mixing as factors regulating primary production in the coastal waters impacted by the Mississippi River plume. Cont Shelf Res 19:1113-1141

Pakulski JD, Benner R, Amon R, Eadie B, Whitledge T (1995) Community metabolism and nutrient cycling in the Mississippi River plume. Mar Ecol Prog Ser 117:207-218

Rabalais NN, Turner RE, Wiseman WJ Jr (1992) Distribution and characteristics of hypoxia on the Louisiana Shelf in 1990 and 1992. In: NOAA Coastal Ocean Program, Nutrient enhanced coastal ocean productivity. Publication No. TAMU-W-91-001. Sea Grant Program, Texas A \& M University, Galveston, TX, p 15-20 
Rabalais NN, Wiseman WJ Jr, Turner RE (1994) Comparison of continuous records of near-bottom dissolved oxygen from the hypoxia zone along the Louisiana coast. Estuaries 17:850-861

Richardson DJ, King GF, Kelly DJ, McEwan AG, Ferguson SJ (1988) The role of auxiliary oxidants in maintaining redox balance during phototrophic growth of Rhodobacter capsulatus on propionate and butyrate. Arch Microbiol 150:131-137

Robertson LA, Kuenen JG (1990) Combined heterotrophic nitrification and aerobic denitrification in Thiosphaera pantotropha and other bacteria. Antonie Leeuwenhoek 57:139-152

Ryther JH, Dunstan WM (1971) Nitrogen, phosphorous and eutrophication in the coastal marine environment. Science 171:1008-1113

Seitzinger SP, Nielsen LP, Caffrey J, Christensen PB (1993) Denitrification measurements in aquatic sediments: a comparison of methods. Biogeochemistry 23(3):147-167

Sloth NP, Blackburn TH, Hansen LS, Risgaard-Petersen N, Lomstein BA (1995) Nitrogen cycling in sediments with different organic loading. Mar Ecol Prog Ser 116:163-170

Sorensen J (1978) Denitrification rates in marine sediment as

Editorial responsibility: Otto Kinne (Editor),

Oldendorf/Luhe, Germany measured by the acetylene inhibition technique. Appl Environ Microbiol 36(1):139-143

Tiedje JM (1988) Ecology of denitrification and dissimilatory reduction of nitrate to ammonium. In: Zehnder AJB (ed) Biology of anaerobic microorganisms. Wiley-Liss, New York, p 179-244

Tiedje JM, Sexstone AJ, Myrold DD, Robinson JA (1982) Denitrification: ecological niches, competition and survival. Antonie Leeuwenhoek 48:569-583

Turner RE, Rabalais NN (1991) Changes in Mississippi River water quality this century. Bioscience 41:140-144

Turner RE, Rabalais NN (1994) Coastal eutrophication near the Mississippi River delta. Nature 368:619-621

Twilley RR, Cowan J, Miller-Way T, Montagna PA, Mortazavi $B$ (1999) Benthic nutrient fluxes in selected estuaries in the Gulf of Mexico. In: Bianchi TS, Pennock JR, Twilley RR (eds) Biogeochemistry of Gulf of Mexico estuaries. WileyLiss, New York, p 163-209

Wang F, Chapman PM (1995) Biological implications of sulfide in sediments - a review focusing on sediment toxicity. Environ Toxicol Chem 18(11):2526-2532

Zumft WG (1997) Cell biology and molecular basis of denitrification. Microbiol Mol Biol Rev 64(4):533-613

Submitted: September 27, 2001; Accepted: May 24, 2002

Proofs received from author(s): August 22, 2002 